\title{
How Executives Manage Interpersonal Conflicts in Chinese Companies in Germany: Intercultural Difference in Conflict Management Styles
}

\author{
Xiang Qian ${ }^{1}$ \\ ${ }^{1}$ Faculty of Economics and Business Administration and the International Resource Industry, TU Bergakademie \\ Freiberg, Germany \\ Correspondence: Xiang Qian, Faculty of Economics and Business Administration and the International Resource \\ Industry, TU Bergakademie Freiberg, Schlossplatz 1a, 09599 Freiberg, Germany. E-mail: \\ xiang.qian@hotmail.com
}

Received: January 20, 2020

Accepted: February 27, 2020

Online Published: March 29, 2020

doi:10.5539/ijbm.v15n4p182

URL: https://doi.org/10.5539/ijbm.v15n4p182

\begin{abstract}
This study aimed to examine the influence of culture on the conflict management styles of Chinese executives when interacting with their German staff in Chinese companies located in Germany. A mixed method was employed. First off questionnaire survey was completed and the data was analyzed with t-test and Pearson Correlation Coefficient methods, then semi-structured interview was conducted and the qualitative content analysis method was used for analysis. This study found that IDV, UAI, IVR dimensions had significant powerful influence on conflict styles of Chinese and German managers; the cultural orientations of Chinese and Germans had also been altered, but their favorite styles remained the same due to the factors, namely: cultural regression, stability of national culture, and various dialectics.
\end{abstract}

Keywords: culture, conflict management, multinational company, Chinese company of Germany

\section{Introduction}

As economic powers with a shared international responsibility in many industries, China and Germany have being established diplomatic relations since the 1970s. Their bilateral economic relationship in particular the trend of Chinese direct investment in Germany characterizes significant change and development of the Sino-German relations. In reference to the Chinese Foreign Direct Investment (FDI) in Germany, Chinese FDI had a sharp increase in 2016, reaching to EUR 11 billion (Mitchell, Chazan \& Weinland, January 11, 2017). Although in 2017 the value of FDI showed a slow decline for the first time in more than a decade due to the screening policies of Germany, the new amendment of such policies being made in last year, such as the amendment to the Foreign Trade and Payments Ordinance provided a lowered threshold in particularly sensitive areas, has given a fresh impetus to Chinese investment. Such subtle variance in Chinese outbound investment cannot change Chinese investors' preference for German market; of EU economies, Germany is still one of the most favorite destination countries for Chinese investors (Hanemann \& Huotari, 2017).

Within an environment beneficial for promotion of investment, the majority of Chinese companies would like to enter German market in acquisitions and mergers (Hanemann \& Huotari, 2015). As they understand that intercultural management must be a testing task for multinational company, they tend to make use of existing resources of German domestic companies, including the know-how, brands and staff, to prevent potential conflicts resulting from cultural difference. For multinational company, the utilization of existing resources is a widely-used way in practice. Intercultural conflict, however, is uneasy to be avoided or handled by this single way. The Survey for Development Conditions of Chinese Companies in Germany being published between 2014 and 2016 by the Chinesische Handelskammer in Deutschland e.V. indicated that intercultural conflict existed everywhere in Chinese companies located in Germany and that intercultural management was one of the biggest obstacles of Chinese companies in business operation in Germany.

For Chinese companies in Germany, as a result of acquisition and merger, their management staff mainly consists of Chinese and German managers coming from a distinguished Eastern and Western culture. "Cultures, especially national cultures, are extremely stable over time" (Hofstede, 2001, p. 34). "[Culture] gives people a 
sense of who they are, of belonging, of how they should behave, and of what they should be doing" (Katsioloudes \& Hadjidakis, 2007, p. 38). "Cultural differences are a prevalent source of contention in intercultural conflict...intercultural conflict often results because of misunderstanding related to different worldviews and communication styles that result from cultural differences" (Ting-Toomey \& Oetzel, 2001, p. 106). There exist thus differences in cultural values between Chinese and Germans. Nowadays, in multinational company, conflict is everywhere and managers face it so often. How to effectively manage conflict has become an important part of intercultural management. A good understanding of different cultures and how culture influences conflict style becomes a requisite for the success of multinational companies, therefore this paper attempts to explore the relationship between cultural value orientation and conflict management style within an intercultural context.

Previous research has argued the importance of cultural difference in conflict resolution and repeatedly found that the differences in the Eastern and Western cultures result in different adoption of conflict strategies. Their focus is on the comparison of China and the USA (e.g. Tsai \& Levenson, 1997; Morris et al. 1998; Xie, Song \& Stringfellow, 1998; Song, Xie \& Dyer, 2000; Peng, He \& Zhu, 2000; Knutson \& Hwang, 2000; Tinsley \& Brett, 2001; Friedman, Chi \& Liu, 2006; Weldon \& Jehn, 2018), although such empirical studies have shed light on the influence of Eastern and Western cultures on conflict resolution. Of these studies, there are a few contributors who have researched different styles of handling conflict between Chinese and Germans. Oetzel et al. (2001) examined different face concerns in conflict situation between different cultural members from China, Germany, Japan and the USA. Oetzel and Ting-Toomey (2003) provided further empirical evidence to suggest that face concerns of different cultural members result in different conflict styles. Brew and Cairns (2004) examined how position, face concerns and conflict management styles connected and mutually affected. These empirical studies, however, are conducted with the main focus on comparing conflict styles of China and some Western developed countries particularly the USA and UK, the sample size and relevant analysis involving Germans are relatively limited.

Scholarly studies in the intercultural and conflict management areas do not widen the focus of their research so far, their main focus of interest in study is still in Chinese and American contexts. Meanwhile, one subtle change is that they began to call for further empirical inquiry into the cultural influence on specific consequence in handling conflict. Merolla et al. (2013) explored the difference in interpersonal forgiveness between Chinese and American cultures and figured out that direct forgiveness could help repair a damaged relationship in both cultures. Zhang et al. (2019) explored how face concern, self-construal and apology affect consequent behaviors in conflict process, including forgiveness, reconciliation and revenge. They found that forgiveness had a negative relationship with independent self-construal and self-face concern, but a positive relationship with interdependent self-construal and other-face concern; in Chinese and American cultures forgiveness was positively related with reconciliation but negatively related with revenge. The overall studies provide sufficient empirical evidence to suggest the relationship between culture and conflict management. Whereas, people have different past experiences and knowledges, their cross-cultural schemata vary with different degrees. It means that the findings being found in Chinese and American contexts cannot be used to indicate cross-cultural schemata in all contexts. Therefore, this paper examines the influence of culture on the conflict management styles of Chinese executives when interacting with their German staff in Chinese companies located in Germany, explores an aspect of conflict management that has received little attention from researchers so far and, thus, makes a valuable contribution to the field.

There is a consensus that culture as the set of values, beliefs, and behavioral patterns being held by a particular nation or group of people can interpret and explain various behaviors. The theory of cultural dimensions is central to discuss and analyze the effect of culture on conflict behavior. Most studies examined how cultures differ in diverse preferred forms of handling conflict within Hofstede's cultural model. Although some scholars criticized the validity of Hofstede's model (e.g. McSweeney, 2002; Blodgett, Bakir \& Rose, 2008), many scholars still hold that Hofstede's model is enough valid and reliable (e.g. Cullen,1999; Herrera \& Erdener, 2009; Finch, 2009). Of these scholarly studies, individualism-collectivism as the key theoretical dimension is often used to examine the influence of culture on conflict styles. Cai and Fink (2002) examined cultural differences in conflict styles between individualistic and collectivistic cultural members and figured out their fundamental difference in conflict styles. Ogretir (2008) constructed the correlation between this dimension and conflict styles. Other scholars also mapped some investigations that utilize different cultural dimensions. Oudenhoven, Mechelse and Dreu (1998) used three dimensions (power distance, uncertainty avoidance, masculinity) of Hofstede's model to measure how culture influences conflict behaviors of people. Purohit \& Simmers (2006) explored intercultural differences in styles of handling conflict based on two dimensions: power distance and 
uncertainty avoidance. Chen, Chao, Xie and Tjosvold (2018) tested how individualism and power distance dimensions as organizational variable influence people's strategy of conflict management. Overall, these scholarly contributions present a partial mapping of cultural influence on conflict management and unique methods for conducting analysis, but they do not address how each cultural dimension individually affects conflict styles within the scope of intercultural conflict management.

In fact, in measurement of cultural difference in conflict styles each cultural dimension can be taken into account for a clearer relationship between culture and conflict styles (Swierczek \& Onishi, 2003). A few researchers took a further tentative step to examine how each dimension of Hofstede's model affect people's conflict behaviors. Peng, He and Zhu (2000) examined how each cultural dimension of Hofstede's model influences employees' styles of handling conflict in company. Mohammed (2008) employed Hofstede's cultural framework to investigate the connection between culture and conflict styles. They offered a relatively clear map of connection between culture and conflict styles, but their findings and explanations are relatively outdated. Specifically, Hofstede's current cultural model consists of six dimensions, but the model they used in study consisted of four or five cultural dimensions, thus their studies cannot provide update findings for the current research of conflict management. More importantly, these scholarly contributions presented relevant issues of foreign invested companies in China including German invested companies in China, few findings or discussions within the scope of Chinese companies in Germany. This paper aims to fill this research gap by examining the role of all cultural dimensions play in deciding a specific conflict style between Chinese and German managers working in Chinese companies located in Germany, providing practical implications for Chinese managers in Germany as well as theoretical implications for the field of intercultural conflict management.

In the following section, this paper first provides some background information on culture and conflict management. Building on these theoretical frameworks, research questions and hypotheses are developed. Next, the hypotheses are tested by using quantitative data, then with combination of qualitative data, the findings of this paper are developed and discussed. In last section, the paper makes a conclusion to assess this study's limitation and to suggest recommendations for future research.

\section{Theoretical Framework}

In early literature conflict is often defined as competition (e.g. Coser, 1967, cited in Dierkes, Antal, Child \& Nonaka, 2003; Mortensen, 1974, cited in Putnam, 2013). The terms competition and conflict are often used synonymously, but essentially the two terms are distinguished, one of the most significant differences is that competition is bound to result in conflict, but conflict may arise either in a competitive or cooperative relationship (Deutsch, 1977). However, "pure cooperation or pure competition; the motive to compete is often mixed with the motive to cooperate" (Walker, 2015, p. 294). In contemporary studies conflict is thus viewed as interactive behaviors among humans rather than a simple competition action (e.g. Folger, Poole \& Stutman, 2001, cited in West \& Turner, 2009; Rahim, 2015). Conflict as a consequence of human interaction is inevitable in organization (Hammer, 2001). For effectively managing conflict, Rahim (1983) and (1985) differentiated the concern for self and for other dimensions and then proposed five-factor styles of conflict-handling: integrating, obliging, dominating, avoiding, and compromising. The integrating style means that an individual has a high concern for both self and others. The obliging style refers to that an individual has a low concern for self and high concern for others. The dominating style refers to a high concern for self and low concern for others. The avoiding style displays a low concern for both self and others. The compromising style refers to a moderate concern for both self and others, not neither high nor low.

Conflict management style is influenced by three factors: cultural context, language differences, and thinking patterns (Chen \& Starosta, 1997). Of them, culture can be seen as the crucial factor in conflict-handling. Culture is intertwined with conflict management. In intercultural encounters, individuals from different cultural societies shape their specific cultural style of interaction with others and the interpretive frame of conflict behavior. How conflict is managed by different cultural members is a constant focus of most researchers. But as described at the beginning of this paper, their main focus is on the comparison of conflict-handling behaviors between Chinese and American cultural members in the scope of multinational companies in China, a relatively small number of them concentrate on examining conflict between Chinese and German cultural members. In existing literature, however, a general review of how Chinese or German culture affects conflict management style is offered. Tang and Kirkbride (1986) figured out that Chinese would like to use ambiguous styles to handle conflict such as avoiding and compromising styles. Ting-Toomey et al. (1991) examined the relationship among culture, face maintenance, and styles of handling conflict and found that Chinese have more tendency to adopt avoiding and compromising styles compared with the people from the West. Tse, Francis and Walls (1994) argued that Chinese managers would like to give or accept negative suggestions like discontinuing or withdrawing while dealing with 
conflict in negotiation. Similar to these scholars, some other scholarly studies also hold that Chinese would like to avoid conflict or make an agreement with different parties involved in conflict because of their conformity tradition (e.g. Morris et al. 1998; Knutson \& Hwang, 2000; Peng, He \& Zhu, 2000; Ma, 2007). Different with Chinese, scholarly studies found that Germans have high tendency to use an explicit attitude while handling conflict, for them an unambiguous statement is a requisite for conflict solution. Specifically, Tinsley (1998) found that German would like to deal with conflict according to specific regulations (cited in London, 1999). Wang et al. (2005) conducted an empirical study and found that Germans had higher willingness to use a solution-oriented way to handle conflict than Asian people.

\section{Research Questions and Hypotheses}

Scholarly studies argued that different cultural groups have different tendencies to adopt conflict management styles. Taking possible differences in conflict management behaviors between Chinese and Germans into consideration, the research question and hypotheses were posed based on each of the theoretical connections between Hofstede's six cultural dimensions and Rahim's five conflict styles as follows. Cultural dimension was as independent variable and conflict management style as dependent variable.

RQ1: How the cultural orientation of Power Distance has influenced the conflict style of Chinese/German managers?

H1a: more likely to adopt the integrating style

H1b: less likely to adopt the obliging style

H1: Managers of high power distance are

H1c: more likely to adopt the dominating

H1d: more likely to adopt the avoiding style

H1e: less likely to adopt the compromising style

RQ2. How the cultural orientation of Individualism-Collectivism has influenced the conflict style of Chinese/German managers?

H2a: less likely to adopt the integrating style

$\mathrm{H} 2 \mathrm{~b}$ : more likely to adopt the obliging style

H2: Managers with collectivistic culture are

$\mathrm{H} 2 \mathrm{c}$ : less likely to adopt the dominating style

H2d: more likely to adopt the avoiding style

H2e: more likely to adopt the compromising style

RQ3. How the cultural orientation of Masculinity has influenced the conflict style of Chinese/German managers?

H3a: more likely to adopt the integrating style

$\mathrm{H} 3 \mathrm{~b}$ : less likely to adopt the obliging style

H3: Managers with masculine culture are

$\mathrm{H} 3 \mathrm{c}$ : more likely to adopt the dominating style

H3d: less likely to adopt the avoiding style

H3e: less likely to adopt the compromising style

RQ4. How the cultural orientation of Uncertainty Avoidance has influenced the conflict style of Chinese/German managers?

H4a: more likely to adopt the integrating style

H4b: less likely to adopt the obliging style

H4: Managers with Low uncertainty avoidance culture are

H4c: more likely to adopt the dominating style

H4d: less likely to adopt the avoiding style

H4e: less likely to adopt the compromising style 
RQ5. How the cultural orientation of Long Term Orientation has influenced the conflict style of Chinese/German managers?

\begin{tabular}{|c|c|}
\hline H5: Managers with long term culture are & $\begin{array}{l}\text { H5a: more likely to adopt the integrating style } \\
\text { H5b: more likely to adopt the obliging style } \\
\text { H5c: less likely to adopt the dominating style } \\
\text { H5d: less likely to adopt the avoiding style } \\
\text { H5e: more likely to adopt the compromising style }\end{array}$ \\
\hline
\end{tabular}

RQ6. How the cultural orientation of Indulgence has influenced the conflict style of Chinese/German managers?

\begin{tabular}{l|l}
\hline \multirow{3}{*}{ H6: Managers with restrained culture are } & $\begin{array}{l}\text { H6a: less likely to adopt the integrating style } \\
\text { H6b: more likely to adopt the obliging style } \\
\text { H6c: less likely to adopt the dominating style } \\
\text { H6d: more likely to adopt the avoiding style } \\
\text { H6e: more likely to adopt the compromising style }\end{array}$ \\
\hline
\end{tabular}

\section{Methodology}

This study was conducted in the scope of Chinese companies in Germany, which are defined as 'subsidiaries or represent offices being directly invested and established in Germany by the parent companies located in the mainland of China, or as holding companies located in Germany that have achieved controlling interest during mergers and acquisitions by the parent companies located in the mainland of China'. The mixed method approach of combining qualitative and quantitative techniques is employed to study empirically, as it provides a wide variety of data to assist answering research questions and enables better inference in particular in the case of receiving relatively small sample for quantitative survey (Hall, 2008). Following a triangulation approach to proceed, the whole empirical study consisted of quantitative and qualitative phases: in the first phase questionnaire survey was conducted and after then semi-structured interview was developed in next phase:

\subsection{Quantitative Phase}

\subsubsection{Participant and Sample Size}

Two instrumentations were used in the design of questionnaire: Hofstede's Value Survey Module and Rahim's ROCI-II Form B. In survey, the sample population was based on the list of Chinese companies in Germany that was compiled in reference to four databases: (a)document gathered by Wirtschafts-und Handelsabteilung der Botschaft der Volksprepublik China in der Bundesrepublik Deutschland; (b)a list of membership companies provided by Die Chinesische Handelskammer in Deutschland e.V.; (c)a list of Chinese companies in Hamburg provided by Handelskammer Hamburg; (d)a list of Chinese companies in Sachsen provided by Wirtschaftsförderung Sachsen GmbH.

In all, questionnaires are distributed to 243 managers via post being derived from the aforementioned list of Chinese companies. 36 managers participated in this survey, who were from various industries such as automobile, logistics and finance and involve different levels of managerial positions. Their age ranged from 20 to 60 years, most of them worked at middle-and top-level managerial position and had more than three years of working experience in Chinese company located in Germany, a few had ten years or even more.

\subsubsection{Variates and Measurement}

The independent variate of quantitative research was Hofstede's six cultural dimensions, dependent variate was Rahim's five conflict management styles Cultural orientation. The quantitative data were gathered in two groups: Chinese and German managers. The questionnaire survey served to examine the cultural orientation of Chinese and German managers in order to find out if there exist intercultural differences, and also to examine their tendency to adopt different styles of handling conflict in order to explore possible difference in their use of conflict strategies. Based on the measurement results concerning cultural orientation and conflict management style, the Pearson Correlation Coefficient was employed to build their linear correlation in order to provide quantitative evidence for testing of hypotheses. 
Six dimensions were used for measurement: Power Distance (PDI), Individualism (IDV), Masculinity (MAS), Uncertainty Avoidance (UAI), Long-term Orientation (LTO), and Indulgence (IVR). The measured results were partly different from Hofstede et al. (2010)'s findings (Table 1). This study found that managers' cultural orientation has been shown alteration with various degrees, main differences were on PDI, MAS, and UAI.

Individual scores of managers on each style were also gathered, five measured styles were Integrating (IN), Obliging (OB), Dominating (DO), Avoiding (AV), Compromising (CO). The independent sample t-test was computed and results showed that except for the DO style, there existed difference between Chinese and German managers on other styles: significant difference on the IN and OB styles ( $p=0.027<0.05 ; \mathrm{p}=0.026<0.05$ ), highly significant difference on the AV and CO styles $(\mathrm{p}=0.000<0.01 ; \mathrm{p}=0.007<0.01)$ (Table 2).

Table 1. Comparison of cultural dimension scores

\begin{tabular}{|c|c|c|c|c|}
\hline \multirow{2}{*}{ Cultural Dimensions } & \multicolumn{2}{|c|}{ China } & \multicolumn{2}{|c|}{ Germany } \\
\hline & by survey & by Hofstede & by survey & by Hofstede \\
\hline PDI & 46 & 80 & 60 & 35 \\
\hline IDV & 20 & 20 & 64 & 67 \\
\hline MAS & 74 & 66 & 38 & 66 \\
\hline UAI & 58 & 30 & 48 & 65 \\
\hline LTO & 83 & 87 & 71 & 83 \\
\hline IVR & 12 & 24 & 49 & 40 \\
\hline
\end{tabular}

Table 2. Difference in conflict management styles measured by independent sample T-Test

\begin{tabular}{|c|c|c|c|c|c|c|}
\hline Group Statistics & & $\mathrm{N}$ & Mean & \multicolumn{2}{|c|}{ Std. Deviation } & Std. Error Mean \\
\hline \multirow{2}{*}{ IN } & \multicolumn{2}{|c|}{ Gernan 12} & 4.119 & \multicolumn{2}{|l|}{.594} & .171 \\
\hline & \multicolumn{2}{|c|}{ Chinese 22} & 3.649 & \multicolumn{2}{|l|}{.548} & .117 \\
\hline \multirow{2}{*}{$\mathrm{OB}$} & \multicolumn{2}{|c|}{ Gernan 12} & 3.139 & \multicolumn{2}{|l|}{.291} & .084 \\
\hline & \multicolumn{2}{|c|}{ Chinese 22} & 2.833 & \multicolumn{2}{|l|}{.398} & .085 \\
\hline \multirow{2}{*}{ DO } & \multicolumn{2}{|c|}{ Gernan 12} & 3.367 & \multicolumn{2}{|l|}{.702} & .203 \\
\hline & Chinese & se 22 & 3.255 & \multicolumn{2}{|l|}{.479} & .102 \\
\hline \multirow{2}{*}{ AV } & \multicolumn{2}{|c|}{ Gernan 12} & 2.236 & \multicolumn{2}{|l|}{.698} & .202 \\
\hline & Chinese & se 22 & 3.265 & \multicolumn{2}{|l|}{.459} & .098 \\
\hline \multirow{2}{*}{$\mathrm{CO}$} & \multirow{2}{*}{$\begin{array}{l}\text { Gernan } \\
\text { Chinese }\end{array}$} & n 12 & 2.854 & \multicolumn{2}{|l|}{.527} & .152 \\
\hline & & se 22 & 3.375 & \multicolumn{2}{|l|}{.493} & .105 \\
\hline \multirow{3}{*}{$\begin{array}{l}\text { Conflict Management } \\
\text { Styles }\end{array}$} & \multicolumn{6}{|c|}{ t-test for Equality of Means } \\
\hline & \multirow{2}{*}{\multicolumn{2}{|c|}{ df Sig. (2-tailed) }} & \multirow{2}{*}{ Mean Difference } & \multirow{2}{*}{ Std. Error Difference } & \multicolumn{2}{|c|}{ 95\% Confidence Interval of the Difference } \\
\hline & & & & & Lower & Upper \\
\hline IN & 2.319 & 32.027 & .470 & .203 & .057 & .882 \\
\hline $\mathrm{OB}$ & 2.336 & 32.026 & .306 & .131 & .039 & .573 \\
\hline DO & .552 & 32.585 & .112 & .203 & -.301 & .526 \\
\hline AV & -5.186 & 32.000 & -1.029 & .198 & -1.433 & -.625 \\
\hline $\mathrm{CO}$ & -2.876 & 32.007 & -.521 & .181 & -.890 & -.152 \\
\hline
\end{tabular}

$\mathrm{p}<0.05$ (significant); $\mathrm{p}<0.01$ (highly significant).

\subsection{Qualitative Phase}

As interviewing emphasizes practical experience of interviewees and interpretation of interviewing questions, it can be seen as a useful qualitative research method to systematically verify the validity of quantitative survey (Hines, 1993). Thus, this study employed semi-structured interview method to complete the qualitative study.

\subsubsection{Interviewee}

This study sought interviewees through three ways: (a) asking wish of having a $n$ interview in questionnaire; (b) re-contacting with managers who participated not in questionnaire survey; (c) having a door-to-door visit. A total of 20 managers coming from different companies accepted a face-to-face interview. Interview began with the interview guide that consisted of three topics, including experience of handling conflict situations; 
reactions to intercultural encounters, judgment on the relationship between culture and conflict management.

\subsubsection{Interviewing and Recording}

Interviews with Chinese managers were conducted in Chinese; interviews with German managers were conducted in English. Each interview was designed to conduct approximately twenty minutes, but the actual length ranged from twenty to forty minutes. All the records were transcribed. After the completion of interviewing, the qualitative content analysis method was used to analyze the interview contents.

First off, these transcribed contents were reviewed, then the contents were condensed into concise and specific paragraphs or sentences, at next these contents were organized within a coding frame that was built according to the interview guide. After analysis, the contents were used to corroborate the quantitative findings of questionnaire survey by quoting original sentences.

\section{Testing Results of Hypotheses}

In reference to the results concerning cultural dimensions and conflict management styles, the correlation between cultural dimension and conflict style was constructed (Table 3). Then, hypotheses were tested and testing results were classified into three types: (1) basically proved, i.e. a hypothesis can be proved by both the t-test and Correlation results; (2) partially proved, i.e. a hypothesis can be proved by the Correlation and t-test results but the linear correlation is not significant; (3) untenable hypothesis.

Table 3. Relationship between cultural dimensions and conflict management styles

\begin{tabular}{|c|c|c|c|c|c|c|}
\hline & & IN & OB & DO & $\mathrm{AV}$ & $\mathrm{CO}$ \\
\hline \multirow{4}{*}{ PDI } & Pearson Correlation & .244 & .045 & .246 & .144 & .279 \\
\hline & Sig. (2-tailed) & .165 & .802 & .161 & .415 & .110 \\
\hline & $\mathrm{N}$ & 34 & 34 & 34 & 34 & 34 \\
\hline & Pearson Correlation & $.453 * *$ & -.147 & $.441 * *$ & -.165 & -.181 \\
\hline \multirow{3}{*}{ IDV } & Sig. (2-tailed) & .007 & .407 & .009 & .351 & .305 \\
\hline & $\mathrm{N}$ & 34 & 34 & 34 & 34 & 34 \\
\hline & Pearson Correlation & $.444 * *$ & -.070 & $.346^{*}$ & -.031 & -.010 \\
\hline \multirow{3}{*}{ MAS } & Sig. (2-tailed) & .008 & .696 & .045 & .860 & .955 \\
\hline & $\mathrm{N}$ & 34 & 34 & 34 & 34 & 34 \\
\hline & Pearson Correlation & -.095 & .216 & .133 & $.355^{*}$ & .311 \\
\hline \multirow{3}{*}{ UAI } & Sig. (2-tailed) & .593 & .219 & .452 & .039 & .074 \\
\hline & $\mathrm{N}$ & 34 & 34 & 34 & 34 & 34 \\
\hline & Pearson Correlation & .157 & .050 & -.107 & -.182 & -.157 \\
\hline \multirow{3}{*}{ LTO } & Sig. (2-tailed) & .376 & .780 & .549 & .304 & .374 \\
\hline & $\mathrm{N}$ & 34 & 34 & 34 & 34 & 34 \\
\hline & Pearson Correlation & .156 & -.051 & .007 & -.252 & -.228 \\
\hline \multirow{2}{*}{ IVR } & Sig. (2-tailed) & .378 & .773 & .968 & .150 & .194 \\
\hline & $\mathrm{N}$ & 34 & 34 & 34 & 34 & 34 \\
\hline
\end{tabular}

**. Correlation is significant at the 0.01 level (2-tailed).

*. Correlation is significant at the 0.05 level (2-tailed).

RQ1 The t-test result showed that Chinese managers with low power distance have a lower mean $(\mathrm{M}=3.649)$ on the IN style than German managers $(\mathrm{M}=4.119)$ with high power distance, but the Correlation was not significant $(\mathrm{r}=0.244, \mathrm{p}=0.165>0.05)$, so H1a was partially supported. For H1b, the t-test result indicated that the mean of Chinese managers $(\mathrm{M}=2.833)$ was lower than that of German managers $(\mathrm{M}=3.139)$ on the OB style, which implied a positive relationship, but the Correlation showed no significant relationship $(\mathrm{r}=0.045, \mathrm{p}=0.802>0.05)$, thus it was partially rejected. H1c, H1d, and H1e were untenable hypotheses.

$R Q 2 \mathrm{H} 2 \mathrm{~b}$ and $\mathrm{H} 2 \mathrm{c}$ were untenable. For $\mathrm{H} 2 \mathrm{a}$, as the $\mathrm{t}$-test result on IN style showed that Chinese managers had a smaller mean $(M=3.649)$ than German managers $(M=4.119)$, and the Correlation was highly significant positive $(\mathrm{r}=0.453, \mathrm{p}=0.007<0.01)$, it was basically supported. As for $\mathrm{H} 2 \mathrm{~d}$, the t-test result on AV style indicated that Chinese managers had a higher mean $(M=3.265)$ than German managers $(M=2.236)$, and the Correlation showed 
no significant relationship $(\mathrm{r}=-0.165, \mathrm{p}=0.351>0.05)$, thus it was partially supported. For H2e, based on the $\mathrm{t}$-test result on $\mathrm{CO}$ style, Chinese managers had a higher mean than German managers $(\mathrm{M}=3.375>\mathrm{M}=2.854)$, and the Correlation result indicated no significant relationship $(\mathrm{r}=-0.181, \mathrm{p}=0.305>0.05)$, so it was partially supported.

$R Q 3$ As for $\mathrm{H} 3 \mathrm{~b}$, on the $\mathrm{OB}$ style the mean of Chinese managers $(\mathrm{M}=2.833)$ was lower than German managers $(\mathrm{M}=3.139)$, which indicated a negative relationship between MAS and the OB style, and the Correlation also indicated a negative relationship but not significant $(\mathrm{r}=-0.070, \mathrm{p}=0.696>0.05)$, thus it was partially supported. Other hypotheses were untenable.

$R Q 4 \mathrm{H} 4 \mathrm{~b}$ and $\mathrm{H} 4 \mathrm{c}$ were untenable. $\mathrm{H} 4 \mathrm{a}$ was partially supported, as the t-test result on the IN style showed that the mean of Chinese managers was smaller $(\mathrm{M}=3.649)$ than German managers $(\mathrm{M}=4.119)$, but the Correlation showed no significant relationship $(\mathrm{r}=-0.095, \mathrm{p}=0.593>0.05)$. For $\mathrm{H} 4 \mathrm{~d}$, the $\mathrm{t}$-test results showed that Chinese managers $(\mathrm{M}=3.265)$ was higher than German managers $(\mathrm{M}=2.236)$, and the Correlation also showed a significant positive relationship $(\mathrm{r}=0.355, \mathrm{p}=0.039<0.05)$, so it was basically supported. As for H4e, the t-test result indicated that Chinese managers had a higher mean $(\mathrm{M}=3.375)$ than German managers $(\mathrm{M}=2.854)$ on $\mathrm{CO}$ style, but the Correlation showed no significant relationship $(\mathrm{r}=0.311, \mathrm{p}=0.074>0.05)$, thus it was partially supported.

$R Q 5$ Its five hypotheses were untenable in this study, so it can be said that this dimension has no influence on the styles of conflict management.

RQ6 H6b and H6c were untenable. As for H6a, the t-test result showed that Chinese managers had a lower mean $(\mathrm{M}=3.649)$ than German managers $(\mathrm{M}=4.119)$ on the $\mathrm{IN}$ style, and the Correlation indicated no significant positive relation $(\mathrm{r}=0.156, \mathrm{p}=0.378>0.05)$, so it was partially supported. As for H6d, the t-test result on the AV style showed that Chinese managers had a higher mean $(M=3.265)$ than German managers $(M=2.236)$, and the Correlation was not significant negative $(r=-0.252, \mathrm{p}=0.150>0.05)$, thus it was partially supported. Similarly, H6e was also partially supported.

\section{Findings and Discussions}

The findings and relevant discussions centered on the hypotheses that were proved partially or basically, because these tested hypotheses could be corroborated or interpreted by the qualitative data through direct quotation. In this study, quantitative and qualitative evidence clearly indicate that not all of cultural dimensions can greatly affect people's adoption of conflict styles, only three of them have significant influence on behaviors of handling-conflict. The empirical evidence of this study also suggest that in cross-cultural context people's cultural value orientation is possible to be altered, but it is noteworthy that their favorite styles of handling conflict are resistant to be changed, i.e. their favorite styles remain the same even though their value orientation have been altered with various degrees. In addition to these, this study used the dialectic thinking theory to explain why Chinese and Germans remain their preference for particular styles in conflict situations.

\subsection{Three Cultural Dimensions of Strong Influence on Conflict Management Styles}

\subsubsection{IDV and Conflict Styles}

This study found that IDV dimension, as the key dimension that can explain many differences and similarities of various intercultural communication behaviors, strongly affects conflict strategies of managers. It has great influence on three styles of conflict management: IN, AV, CO.

Chinese managers were examined as collectivistic orientation and German managers as individualistic orientation in this study. It is requisite for the adoption of IN style to express opinions or needs in direct way. Chinese managers with collectivistic orientation would like to emphasize the division between in-group and out-group members, and the interdependent self-construal. While dealing with conflict, first off Chinese managers tend to identify who are in-group members or out-group members, since they would not like to speak up their real standpoints while facing with their in-group members, in order to prevent from destroying the interests or face of in-group members. Furthermore, for Chinese managers, the trait of interdependent self-construal also drives them to have a strong willingness of building a high mental relationship with in-group members, thus they would be worried that their contradiction or different ideas weaken or negatively affect the relationship with other in-group members. As one manager said that "while facing disputes, it's better to ignore them or resolve them privately rather than in public...sometimes it's not good to discuss problems in front of other colleagues...may have some negative influence, weakening relationship" (personal communication, October 06, 2016). It is obvious that this cultural orientation of emphasizing division of in-and out-group and the interdependence on in-group members makes Chinese managers have more tendency to give up the use of IN 
style. With a similar logic, the cultural trait of emphasizing individual interest implied by individualism should become one of the main reasons why German managers are more willing to use the IN style.

Chinese managers have more tendency to use the AV and CO styles than German managers. Theoretically, due to the collectivistic orientation of Chinese managers, they concentrate on the harmonious relationship among individuals, which makes them have a high tendency to spontaneously ignore conflict and to reach an agreement with conflict parties or even change their standpoints in order to protect their relationship with others. This inference can also be corroborated by interview contents. One Chinese manager said, "If conflict doesn't affect the proceeding of our tasks, I'd like to ignore them... when I have to handle it, the relationship between me and colleagues may be affected" (personal communication, October 17, 2016). Another similar argument is that "harmony is a tradition of China... here[Chinese companies in Germany] to have a good relationship among our staff is also important, it gives us a good climate for work and a higher efficiency" (personal communication, September 29, 2016). The focus on harmonious relationship is also demonstrated by the contents of a few German managers, who mentioned that Chinese colleagues often invite them to have a "formal Chinese dinner" after working (personal communication, September 08 \& September 12, 2016).

\subsubsection{UAI and Conflict Styles}

This study also concludes that UAI dimension has a strong influence on the adoption of conflict styles. Similar to IDV dimension, three styles affected by UAI dimension are IN, AV, and CO styles.

There exists a negative relationship between UAI and IN style: the lower UAI managers are, the more likely they are to adopt the IN style. Chinese managers were examined with a higher score on UAI than German managers, thus Chinese managers should have less willingness to use the IN style in conflict management. The Survey for Development Conditions of Chinese Companies in Germany showed that some difficulties such as visa application of Chinese employees and limitation of entrance in particular industries often make Chinese managers feel threatened (Chinesische Handelskammer in Deutschland e.V., 2016). After Chinese companies enter into German market, such difficulties and possible unknown factors increase Chinese manager's cultural orientation of worrying or avoiding uncertain situations. The adoption of IN style aims to achieve a win-win result, which is not easy to meet and often requires a flexible way of handling conflict, in this case some change or breaking of existing rules may arise. In return, Chinese managers, who are with a comparatively higher UAI and have a high anxiety of uncertain situations, are less willing to use the IN style. As one manager said that "...when I worked in parent company[located in China], it's easy to change ways to deal with conflict based on the situation, as a Chinese saying 'no matter what rule exists there, we can change it to adapt us'...now I work here[Chinese companies in Germany], I found we have to obey many rules, if we break them easily, many troubles come to us, so we should follow every rule. A good result is important, but at present, avoiding some troubles even is more important" (personal communication, October 24, 2016).

A positive relationship exists between $\mathrm{UAI}$ and the $\mathrm{AV}$ and $\mathrm{CO}$ styles, the correlation between $\mathrm{UAI}$ and AV style is significant. In reference to this, Chinese managers, who are with a higher sore on UAI than German managers, have more tendency to use AV style in handling conflict. Due to higher anxiety over unknown situations, Chinese managers as direct operators in German market often feel stressed. One manager described that "here everything is better, good salary and environment, [but I must learn many things], understand different cultures and different people...I've been here for many years, such feeling doesn't weaken, so stressed" (personal communication, October 13, 2016). The result of questionnaire survey also showed that most Chinese managers have a similar high degree of anxiety. Their degree of nervousness can be seen as a reflection of their high anxiety over uncertain situations. In the case of being unable to avoid conflict, they have to share some resources to seek a temporary resolution of conflict, reducing their feeling of anxiety as much as possible. From this perspective, perhaps it is not difficult to understand that why Chinese, compared with Germans, would be more likely to ignore conflict and avoid direct handling of conflict, or to make compromise in exchange of solution.

\subsubsection{IVR and Conflict Styles}

It is also defined that IVR dimension can affect managers' use of handling-conflict styles. As this dimension is comparatively new, its relationship with conflict management styles are seldom examined by scholars. In this study, it figured out that there exists relationship between IVR and three styles: being positively related with IN style, being negatively related with $\mathrm{AV}$ and $\mathrm{CO}$ styles. Although these relationships are not significant, this study argues that the cultural orientation of IVR can affect the adoption of three conflict styles and its role should be paid more attention in the research field of intercultural management.

The relationship between IVR and IN style is partially defined: Chinese managers with restraint orientation are not inclined to use the IN style, however, the interview contents corroborated this inference. One Chinese 
manager said, "...while meet a conflict, I like to listen [rather than] tell my views...just let things go, for a good relationship...less trouble, less stress, it's important for me" (personal communication, September 28, 2016). Another manager also held a similar view that "maybe it's not good to discuss problems [in all cases] ... we need to learn how to hide them, sometimes [this way]can give us more chances, [reaching for] a happy ending of problems" (personal communication, October 27, 2016). Expression of opinions in public is the prerequisite of using the IN style, but Chinese managers' descriptions show that they would like to control their personal needs or desires, thus they are less likely to speak up their different views or impose such views on others in a verbal way. Different from Chinese, one German manager said that "...I know the way we do things may be not the way other cultures do things...but I like direct communication, it's good for solving conflicts" (personal communication, October 31,2016 ). It can be observed that Germans with indulgent orientation should be more likely to use the IN style.

Chinese have more tendency to use the $\mathrm{AV}$ and $\mathrm{CO}$ styles in handling conflict than Germans, which is corroborated by the interview contents. One Chinese said, "...if I have choice, I'd like to avoid public discussion of problems...[even in condition of] sharing some interests" (personal communication, October 07, 2016). Similarly, another manager also stated that "I just listen, sometimes people just need to talk their needs...if I can solve them soon, I like to give up some interests" (personal communication, October 27, 2016). In addition, the reason for why Chinese prefer to adopt the two styles may be similar to the reason for why they do not like to use the IN style. Because of the restraint orientation, Chinese are used to control their real thinking while handling conflict. In return, they are more conscious to ignore conflict and reach a compromise in exchange for a fast but temporary resolution of conflict.

\subsection{Whether Alteration of Value Orientation Influences Preferred Styles or Not?}

In this study, cultural orientations of Chinese and German managers were examined to be altered in varying degrees. Logically, such alteration of cultural orientations might affect conflict behaviors. But in fact, Chinese still prefer the $\mathrm{AV}$ and $\mathrm{CO}$ styles, they have an implicit or ambiguous attitude to conflict management rather than problem-solving oriented attitude; Germans, who are likely to express their real thinking in a direct way and use an explicit or problem-solving oriented way to handle conflict, are examined as more willing to use the IN style. In this case, a thought-provoking question arises: why does the preference of Chinese and Germans on conflict management styles remain the same under the condition that their cultural orientations have shown alterations? This could be interpreted from two factors:

\subsubsection{Limited Influence of Cultural Regression Phenomenon}

The alteration of cultural orientations can be seen as a result of the phenomenon of cultural regression. Chinese companies in Germany is an intercultural context, in which Chinese and German managers should know each other and be adapted with this environment for keeping their positions stable and safe. The majority of managers have a strong wish to understand different cultures, the cultural regression naturally appears. From this perspective, a few alterations of cultural orientation might not be difficult to understand.

It is noteworthy that this phenomenon is not permanent but temporary and purposive because of some certain elements like job security, thus it has few possibilities to alter basically cultural value orientation of individuals. In intercultural context, managers from various cultural societies attempt to adapt with each other even imitate similar behavioral patterns of others in order to build a harmonious relationship or protect their positions and benefits. Hypothetically, if one manager switches his or her job in a new company which is just a domestic firm with single cultural context, his or her interests in understanding or imitating behavioral patters of different cultures would reduce even disappear, since it seems comparatively easier to establish a good relationship in a single-cultural environment. It can be said that alteration of cultural orientation influenced by cultural regression is a temporary consequence, in return such alterations play a limited role in the use of conflict management strategies.

\subsubsection{Deep Influence and Stability of National Culture}

The stability character of national culture may reduce ambiguity and facilitate a better control over expected behaviors (Weick \& Quinn, 1999). In learning national culture, the values are resistant to be changed, i.e. when people face with other values opposite to their original values, they have tendency to re-arrange the order of these values rather than change their original values (Ravlin, Thomas, \& Ilsev, 2000). More importantly, the learning of national culture is a process of socialization, in which cultural identity is created and "...influences both verbal and nonverbal communication, the propensity to engage in conflict, conflict behaviors, and attitudes about conflict resolution" (Wenning, 2003, p. 87). Through stereotyping, cultural identity affects individual behaviors profoundly (Remland, Jones, Foeman \& Arevalo, 2015). For example, Chinese managers have a 
cultural identity that makes them form a stereotype of focusing on collectivistic interests, on the contrary the cultural identity of German managers makes them form a stereotyping of focusing on personal interests. Under the influence of such stereotypes, while facing with group interests, Chinese managers show more tendency to give up individual interest than German managers. As such stereotypes are stable, conflict behaviors affected through stereotyping also resist to be changed. National culture and relevant value orientations have thus lasting and profound impact on conflict behaviors in organization (e.g. Smith, Dugan \& Trompenaars, 1996; Tsui, Nifadkar \& Ou, 2007).

\subsection{Whether Dialectical Thinking influences Preferred Styles or Not?}

Chinese philosopher Feng Youlan (1926) argued, "the difference between oriental and western cultures is because their basic thought is different. Their basic thought is their philosophy (view of values)" (cited in Chen, 2009, p.169). Philosophical ideas can be expressed through dialectic that is the crucial form in classical philosophy. The dialectical thinking is generated and improved in the development of a society, which affects people's behavioral patterns. Scholarly studies also gave empirical evidence on the influence of dialectical thinking on people's patterns of behaving and perceiving contradiction (e.g. Peng \& Nisbett, 1999; Spencer-Rodgers, Williams \& Peng, 2010; Fang, 2014). It can be said that different dialectics in Chinese and German cultures can be viewed as wisdom of handling conflict, clearly distinguishing conflict behaviors of Chinese and German managers. Thus, different dialectics in Chinese and German cultures are used to offer a further interpretation of preferred conflict styles,

There are two classic schools of thought that are reflective of Chinese dialecticism: Taoism and Confucianism. The thinking of the two dialecticism makes Chinese managers remain the preference on the adoption of $\mathrm{AV}$ and CO styles. Taoism provides a system of thinking about how understand the world works, one of its basic concepts is Non-Duality that is explained in details in Tao Te Ching written by Laozi. Laozi states: “有无相生, 难易相成, 长短相形, 高下相盈, 音声相和, 前后相随 (And so, being and nonbeing produce each other; difficulty and ease complete each other; long and short contrast each other; high and low distinguish each another; sounds and tones harmonize each other; front and back accompany each other)". In reference to this statement, any conflict has two different sides that exist in active harmony, being mutually opposed and connected at the same time. This implies that people should learn to use Wu Wei(no action) strategy to handle them i.e. letting opposites go in natural way without intervention. This dialectical thinking has significant influence on how Chinese deal with conflict. When they are in conflict situation, they always like to say that "祸 兮福所倚, 福兮祸所伏(Good fortune follows upon disaster, disaster lurks within good fortune)", consequently they are unlikely to directly face with contradiction and handle them with ambiguous attitude other than direct attitude.

Confucianism provides a system of thinking about harmony. One of the most significant idealist philosophical ideas is the idea of Zhongyong, that is described in Conficius's books, Doctrine of the Mean: Zhongyong (unwobbling pivot). This idea drives people to take a neutral standpoint and always be in harmony without extreme viewpoints or emotions, which act as the only necessary condition for resolution of problem. The theoretical basis of Zhongyong is 天人合一 (harmony between nature and humanity) which attaches great importance to harmonious relationship. As Lun (2012) said, "the high value placed on harmony is probably the most representative characteristic of Chinese culture" (p. 467). The dialectical thinking of focusing harmony leads Chinese to be more willing to adopt AV and CO styles, since in Chinese culture the two styles are positively related with harmony. In conflict-handling, they seek for a solution with the main focus on harmonious relationship and often keep from going to extremes in conflict management. Under the influence of these dialectics deriving from Taoism and Confucianism, Chinese hold that any events or objects are necessary parts as the whole, which should be given tolerance or respect without aggressive intervention. This can be seen as one kind of oneness thinking pattern.

Germans hold another different thinking pattern. German dialectical thinking is affected fundamentally by Hegelianism. According to the pattern of Hegel's thinking, a series of phases during each process of development are composed of three parts: affirmation, negation, and the negation of negation (Hegel, 2008), thus Germans' treatment and attitude with conflict are linked with synthesis. Unlike Chinese, Germans have no absolute tolerant attitude towards contradiction, but an alienate spirit while handling conflict. First off, they affirm conflict, at next negate it and then negate their previous negations, which forms a circle of development by repeating in this way. As a result, they are able to achieve a new idea, i.e. a final resolution to preliminary conflict will be found. This dialectical thinking leads to their direct problem-solving attitude and preference of the IN style while handling conflict, in other words they would like to think about conflict with dividedness idea and to directly face appositive ideas and openly express differences of opinions. 
In sum, harmony characterizes Chinese dialectical thinking, the key feature of German dialectical thinking is characterized as integrating. Thus, it is inevitable that Chinese and Germans show different preference for conflict-handling strategies and remain their favorite styles in intercultural context. For instance, in Chinese companies located in Germany, while facing with conflict occurring in superior-subordinate relationship, Chinese managers seldom criticize the performance of their subordinates directly in public, but often have a one-to-one talk or give indirect information or suggestions to motivate subordinates to enhance their performance. For Chinese, conflict is a natural part in organization and should be totally accepted by members, thus they have few tendencies to handle conflict in a polarized way. Unlike Chinese, Germans would like to seek a direct strategy for conflict resolution, thus usually criticize or judge the performance of their subordinates in workplaces. It can be observed that while managing conflict there exists a polar opposition between Chinese' pursuit of morality and Germans' pursuit of truth. In their different patterns of thinking, Chinese and Germans are bound to adopt different styles to handle conflict. Chinese, who lay high emphasis on harmonious relationship, are more likely to treat with conflict by catering to others or staying away from disagreement or contradiction; Germans, who would like to put conflict into separate parts and consider the parts in their dialectic in line with Hegelianism, are more likely to explain or discuss positive and negative aspects of conflict with the aim of seeking a solution in interaction process.

\section{Conclusions}

The main limitation of this study is that a clearer mapping of the relationship between Hofstede's cultural dimension and Rahim's conflict style should be desirable. Perhaps other theories such as Hall and Trompenaars' models would have allowed for another interpretation for such correlation in order to achieve a clearer correlation. This study employed, however, the dialectical thinking theory to help explain why Chinese and Germans have different tendency to use different strategies in conflict resolution, providing further clues to the correlation between cultural value orientation and conflict management styles from another perspective.

Overall, this study provides some new light on the correlation between cultural value orientation and conflict management styles in intercultural context. In existing literature, most studies used cultural dimensions within Hofstede's model, but they mostly examined how individualism dimension affects conflict styles. Compared with them, this study measured all six dimensions and based on sufficient empirical evidence figured out their relationship with conflict styles, providing a deep knowledge of how different cultures affect behaviors of handling-conflict in intercultural encounters. The findings of this study may contribute to the improvement of intercultural research, offering practical guidance for Chinese and German managers. Moreover, this study breaks new research ground because of its focus on Chinese companies in Germany, as in previous Sino-German studies most studies focus on German companies in China.

Although these findings of this study have shed some light on the influence of culture on conflict management, more research is needed in order to fully understand how people's cultural value orientation affect their strategies while handling conflict. As such, this study revealed that three dimensions make stronger influence on conflict strategies and that Chinese and German managers have been showing a similar orientation on some cultural dimensions. Future research may seek to test such findings, thus more new or wider insights could be obtained and more valuable practical and theoretical guidelines for managers and professionals in global business would also be acquired.

\section{Acknowledgments}

The author gratefully acknowledges the funding for this study from the China Scholarship Council (CSC). This study was developed based on the author's dissertation research project. The author acknowledges the insightful suggestions from Prof. Michael B. Hinner and Prof. Xiaodong Dai, and is also grateful for the support of the Chinese embassy in Germany, involved authorities and companies as well as managers participated in this study.

\section{References}

Alagözlü, N. (2017). Cross cultural conflict resolution styles: Data revisited. International Online Journal of Education and Teaching, 4(3), 199-211.

Blodgett, J. G., Bakir, A., \& Rose, G. M. (2008). A test of the validity of Hofstede's cultural framework. Advances in Consumer Research, 35, 762-763. https://doi.org/10.1108/07363760810902477

Brew, F. P., \& Cairns, D. R. (2004). Styles of managing interpersonal workplace conflict in relation to status and face concern: A study with Anglos and Chinese. International Journal of Conflict Management, 5(1), 27-56. https://doi.org/10.1108/eb022906

Cai, D., \& Fink, E. (2002). Conflict style differences between individualists and collectivists. Journal of 
Communication Monographs, 69(1), 67-87. https://doi.org/10.1080/03637750216536

Chao, M. C., Xie, H., \& Tjosvold, D. (2018). Transforming cross-cultural conflict into collaboration: The integration of western and eastern values. Cross Cultural \& Strategic Management, 25(1), 70-95. https://doi.org/10.1108/CCSM-10-2016-0187

Chen, L. (2009). Tradition and modernity: A humanist view (translated by Edmund R.). Leiden, NED: Koninklijke Brill. https://doi.org/10.1163/ej.9789004165786.i-386

Chen, G. M., \& Starosta, W. J. (1997). Chinese conflict management and resolution: Overview and implications. Intercultural Communication Studies, 7, 1-16.

Chen, N., Chao, M. C., Xie, H., \& Tjosvold, D. (2018). Transforming cross-cultural conflict into collab oration. Cross Cultural \& Strategic Management, 25(1), 70-95. https://doi.org/10.1108/CCSM-10-201 6-0187

Chinesische Handelskammer in Deutschland e.V. (Chinese Chamber of Commerce in Germany). (2014). Survey for development conditions of Chinese companies in Germany. Berlin: Author.

Chinesische Handelskammer in Deutschland e.V. (Chinese Chamber of Commerce in Germany). (2015). Survey for development conditions of Chinese companies in Germany. Berlin: Author.

Chinesische Handelskammer in Deutschland e.V. (Chinese Chamber of Commerce in Germany). (2016). Survey for development conditions of Chinese companies in Germany. Berlin: Author.

Cullen, J. B. (1999). Multinational management: A strategic approach. Cincinnati, Ohio: South-Western College Publishing.

Deutsch, M. (1977). The resolution of conflict: Constructive and destructive processes (2nd ed.). New Haven: Yale University Press.

Dierkes, M., Antal, A. B., Child, J., \& Nonaka, I. (2003). Handbook of organizational learning and knowledge. Oxford: Oxford University Press.

Elsayed-Ekhouly, S. M., \& Buda, R. (1996). Organizational conflict: A comparative analysis of conflict styles across cultures. International Journal of Conflict Management, 7(1), 71-81. https://doi.org/10.1 108/eb022776

Fang, T. (2014). Understanding Chinese culture and communication: The Yin Yang approach. In Gehrke, B. \& Claes, M. T. (Eds.), Global leadership practices (pp. 171-187). London: Palgrave Macmillan. https://doi.org/10.1007/978-1-137-35001-5_10

Finch, N. (2009). Towards an understanding of cultural influence on the international practices of accounting. Journal of International Business and Cultural Studies, 2(1), 1-6.

Fisher-Yoshida, B. (2005). Reframing conflict: Intercultural conflict as potential transformation. Journal of Intercultural Communication, 8, 1-16.

Friedman, R., Chi, S. C., \& Liu, L. A. (2006). An expectancy model of Chinese-American differences in conflict-avoiding. Journal of International Business Studies, 37(1), 76-91. https://doi.org/10.1057/palgrave.jibs. 8400172

Hall, R. (2008). Applied social research: Planning, designing and conducting real-world research. South Yarra, Australia: Palgrave Macmillan.

Hammer, M. R. (2001). Conflict negotiation under crisis conditions. In Eadie, W. F., \& Nelson, P. E. (Eds.), The language of conflict resolution (pp. 57-80). California: SAGE Publications. https://doi.or $\mathrm{g} / 10.4135 / 9781452205496 . \mathrm{n} 5$

Hanemann, T., \& Huotari, M. (2015). Chinese FDI in Europe and Germany: Preparing for a new era of Chinese capital (report by Mercator Institute for China Studies and Rhodium Group). Retrieved from http://rhg.com/wp-content/uploads/2015/06/ChineseFDI_Europe_Full.pdf

Hanemann, T., \& Huotari, M. (2017). Record flows and growing imbalances (report by Mercator Institut e for China Studies and Rhodium Group). Retrieved from https://www.merics.org/fileadmin/user_uplo ad/downloads/MPOC/COFDI_2017/MPOC_03_Update_COFDI_Web.pdf

Herrera, J. M., \& Erdener, C. (2009). Western ethical theories and their relevance to HRM in Latin America. In Davila, A. \& Elvira, M. M. (Eds.), Best human resource management practices in Latin America (pp.157-169). Abingdon, Oxon: Routledge. 
Hines, A. M. (1993). Linking qualitative and quantitative methods in cross-cultural survey research: Techniques from cognitive science. American Journal of Community Psychology, Vol. 21, Iss. 6, 729-746. https://doi.org/10.1007/BF00942245

Hofstede, G. (2001). Culture's consequences: Comparing values, behaviors, institutions and organizations across nations (2nd ed.). Thousand Oaks: SAGE Publications.

Hofstede, G., Hofstede, G. J., \& Minkov, M. (2010). Cultures and organizations: Software of the mind (3rd ed.). New York: McGraw-Hill.

Katsioloudes, M. I., \& Hadjidakis, S. (2007). International business: A global perspective. Burlington: Butterworth-Heinemann. https://doi.org/10.4324/9780080471464

Knutson, T. J., \& Hwang, J. C. (2000). Perception and management of conflict: A comparison of Taiwanese and US Business Employees. Intercultural Communication Studies, 9, 1-32.

LeBaron, M. (2013). Culture and conflict. Retrieved from http://www.beyondintractability.org/essay/culture -conflict

London, M. (1999). Principled leadership and business diplomacy: Values-based strategies for management development. Westport, CT: Quorum Books. https://doi.org/10.1108/02621719910257783

Ma, Z. Z. (2007). Competing or accommodating? An empirical test of Chinese conflict management styles. Contemporary Management Research, 3(1), 3-22. https://doi.org/10.7903/cmr.12

McSweeney, B. (2002). Hofstede's model of national cultural differences and their consequences: A triumph of faith-a failure of analysis. In Clegg, S. R. (Ed.), SAGE directions in organization studies (Volume I-IV) (pp. 87-114). London: SAGE Publications.

Merolla, A. J., Zhang, S., \& Sun, S. (2013). Forgiveness in the United States and China: Antecedents, Consequences, and Communication Style Comparisons. Communication Research, 40(5), 595-622. https://doi.org/10.1177/0093650212446960

Mitchell, T., Chazan, G., \& Weinland, D. (January 11, 2017). Chinese investment in EU dwarfs flow the other way. Financial Times. Retrieved from https://www.ft.com/content/79e3a2b2-d6f7-11e6-944b-e7eb37a6aa8e

Mohammed, U. K. (2008). Culture and conflict management style of international project managers. International Journal of Business and Management, 3(5), 3-11. https://doi.org/10.5539/ijbm.v3n5p3

Morris, M. W., Williams, K. Y., Leung, K., Larrick, R., Mendoza, M. T., Bhatnagar, D., ...Hu, Jun-Chen. (1998). Conflict management style: Accounting for cross-national differences. Journal of International Business Studies, 29(4), 729-747. https://doi.org/10.1057/palgrave.jibs.8490050

Oetzel, J., Ting-Toomey, S., Masumoto, T., Yumiko, Y., Pan, X. H., ...\& Wilcox, R. (2001). Face and facework in conflict: A cross-cultural comparison of China, Germany, Japan, and the United States. Communication Monographs, 68(3), 235-258. https://doi.org/10.1080/03637750128061

Oetzel, J., \& Ting-Toomey, S. (2003). Face concerns in interpersonal conflict: A cross-cultural empirical test of the face negotiation theory. Communication Research, 30(6), 599-624. https://doi.org/10.1177/0093650203257841

Ogretir, A. D. (2008). The relationship between culture and the conflict resolution styles: A survey method and a statistical analysis. Middle-East Journal of Scientific Research, 3(2), 96-104.

Oudenhoven, J. P., Mechelse, L., \& Dreu, C. K. W. (1998). Managerial conflict management in five European countries: The importance of Power Distance, Uncertainty Avoidance, and Masculinity. Applied Psychology, 47(3), 439-455. https://doi.org/10.1111/j.1464-0597.1998.tb00037.x

Peng, K., \& Nisbett, R. E. (1999). Culture, dialectics, and reasoning about contradiction. American Psychologist, 54(9), 741-754. https://doi.org/10.1037/0003-066X.54.9.741

Peng, S. Y., He, Z., \& Zhu, J. H. (2000). Conflict management styles among employees of Sino-America, Sino-French, and State-owned enterprises in China. Intercultural Communication Studies, 9, 33-46.

Putnam, L. L. (2013). Definitions and approaches to conflict and communication. In Oetzel, J. G., \& Ting-Toomey, S. (Eds.), The SAGE handbook of conflict communication (2nd ed., pp. 1-39). Thousand Oaks: SAGE Publications.

Purohit, Y. S., \& Simmers, C. A. (2006). Power Distance and Uncertainty Avoidance: A cross-national examination of their impact on conflict management modes. Journal of International Business Research, 
5(1), 1-19.

Rahim, M. A. (1983). A measure of styles of handling interpersonal conflict. Academy of Management Journal, 26(2), 368-376. https://doi.org/10.5465/255985

Rahim, M. A. (1985). A strategy for managing conflict in complex organizations. Human Relations, 38(1), 81-89. https://doi.org/10.1177/001872678503800105

Rahim, M. A. (2015). Managing conflict in organizations (4th ed.). New Brunswick, USA: Transaction Publishers.

Ravlin, E. C., Thomas, D. C., \& Ilsev, A. (2000). Beliefs about values, status, and legitimacy in multicultural groups: Influences on intragroup conflict. In Earley, P. C., \& Singh, H. (Eds.), Innovation in international cross-cultural management (pp. 17-51). Thousand Oaks: SAGE Publications. https://doi.org/10.4135/9781452205502.n2

Remland, M. S., Jones, T. S., Foeman, A., \& Arevalo, D. R. (2015). Intercultural communication: A peacebuilding perspective. Long Grove, IL: Waveland Press.

Smith, P. B., Dugan, S., \& Trompenaars, F. (1996). National culture and the values of organizational employees. Journal of Cross-Cultural Psychology, 27(2), 231-264. https://doi.org/10.1177/0022022196272006

Song, X. M., Xie, J. H., \& Dyer, B. (2000). Antecedents and consequences of marketing managers' conflict-handling behaviors. Journal of $\quad$ Marketing, 64(1), https://doi.org/10.1509/jmkg.64.1.50.17989

Søndergaard, M. (1994). Research note: Hofstede's consequences: A study of reviews, citations and replications. Organization Studies, 15(3), 447-456. https://doi.org/10.1177/017084069401500307

Spencer-Rodgers, J., Williams, M. J., \& Peng, K. (2010). Cultural differences in expectations of change and tolerance for contradiction: A decade of empirical research. Personality and Social Psychology Review, 14(3), 296-312. https://doi.org/10.1177/1088868310362982

Swierczek, F. W., \& Onishi, J. (2003). Culture and conflict: Japanese managers and Thai subordinates. Personnel Review, 32(2), 187-210. https://doi.org/10.1108/00483480310460216

Tang, S. F. Y., \& Kirkbride, P. S. (1986). Developing conflict management skills in Hong Kong: An analysis of some cross-cultural implications. Management Learning, 17(3), 287-301. https://doi.org/10.1177/135050768601700315

Ting-Toomey, S., Gao, G., Trubisky, P., Yang, Z. Z., Kim, H. S... \& Nishida, T. (1991). Culture, face maintenance, and styles of handling interpersonal conflict: A study in five cultures. International Journal of Conflict Management, 2(4), 275-296. https://doi.org/10.1108/eb022702

Ting-Toomey, S. (1999). Communicating across cultures. New York: The Guilford Press.

Ting-Toomey, S., \& Oetzel, J. G. (2001). Managing intercultural conflict effectively. California: SAGE Publications.

Tinsley, C. H., \& Brett, J. M. (2001). Managing workplace conflict in the United States and Hong Kong. Organizational Behavior and Human Decision Processes, 85(2), 360-381. https://doi.org/10.1006/obhd.2000.2944

Tsai, J. L., \& Levenson, R. W. (1997). Cultural influences on emotional responding Chinese American and European American dating couples during interpersonal conflict. Journal of Cross-Cultural Psychology, 28(5), 600-625. https://doi.org/10.1177/0022022197285006

Tse, D. K., Francis, J., \& Walls, J. (1994). Cultural differences in conducting intra-and inter-cultural negotiations: A Sino-Canadian comparison. Journal of International Business Studies, 25(3), 537-555. https://doi.org/10.1057/palgrave.jibs.8490211

Tsui, A. S., Nifadkar, S. S., \& Ou, A. Y. (2007). Cross-national, cross-cultural organizational behavior research: Advances, gaps, and recommendations. Journal of Management, 33(3), 426-478. https://doi.org/10.1177/0149206307300818

Walker, R. (2015). Strategic management communication for leaders (3rd ed.). Stamford: Cengage Learning.

Wang, C. L., Lin, X. H., Chan, A. K. K., \& Shi, Y. Z. (2005). Conflict handling styles in international joint ventures: a cross-cultural and cross-national comparison. Management International Review, 45(1), 3-21. 
Weick, K. E. \& Quinn, R. E. (1999). Organizational change and development. Annual Review of Psychology, 50, 361-386. https://doi.org/10.1146/annurev.psych.50.1.361

Weldon, E., \& Jehn, K. A. (2018). Conflict management in US-Chinese joint ventures. In Child, J. \& Lu, Y. (Eds.), Management issues in China: Volume II International enterprises (chapter 5). Abingdon, Oxon: Routledge.

Wenning, M. (2003). Experiential learning: Culture and conflict. In Pammer, W. J. \& Killian, J. (Eds.), Handbook of conflict management (pp. 85-100). New York: Marcel Dekker.

West, R., \& Turner, L. H. (2009). Understanding interpersonal communication: Making choices in changing times (2nd ed.). Boston, MA: Wadsworth Cengage Learning.

Wicks, R. (2015). Personal and professional management. In Smith, R., King, D., Sidhu, R. \& Skelsey, D. (Eds.), The effective change manager's handbook: Essential guidance to the change management body of knowledge (pp. 492-534). London: Kogan Page Limited.

Xie, J. H., Song, X. M., \& Stringfellow, A. (1998). Interfunctional conflict, conflict resolution styles, and new product success: A four-culture comparison. Management Science, 44(12), 192-206. https://doi.org/10.1287/mnsc.44.12.S192

Yuan, W. L. (2010). Conflict management among American and Chinese employees in multinational organizations in China. Cross Cultural Management, 17(3), 299-331. https://doi.org/10.1108/13527601011068388

Zhang, Q., Oetzel, J. G., Ting-Toomey, S., \& Zhang, J. B. (2019). Making up or getting even? The effects of face concerns, self-construals, and apology on forgiveness, reconciliation, and revenge in the United States and China. Communication Research, 46(4), 503-524. https://doi.org/10.1177/0093650215607959

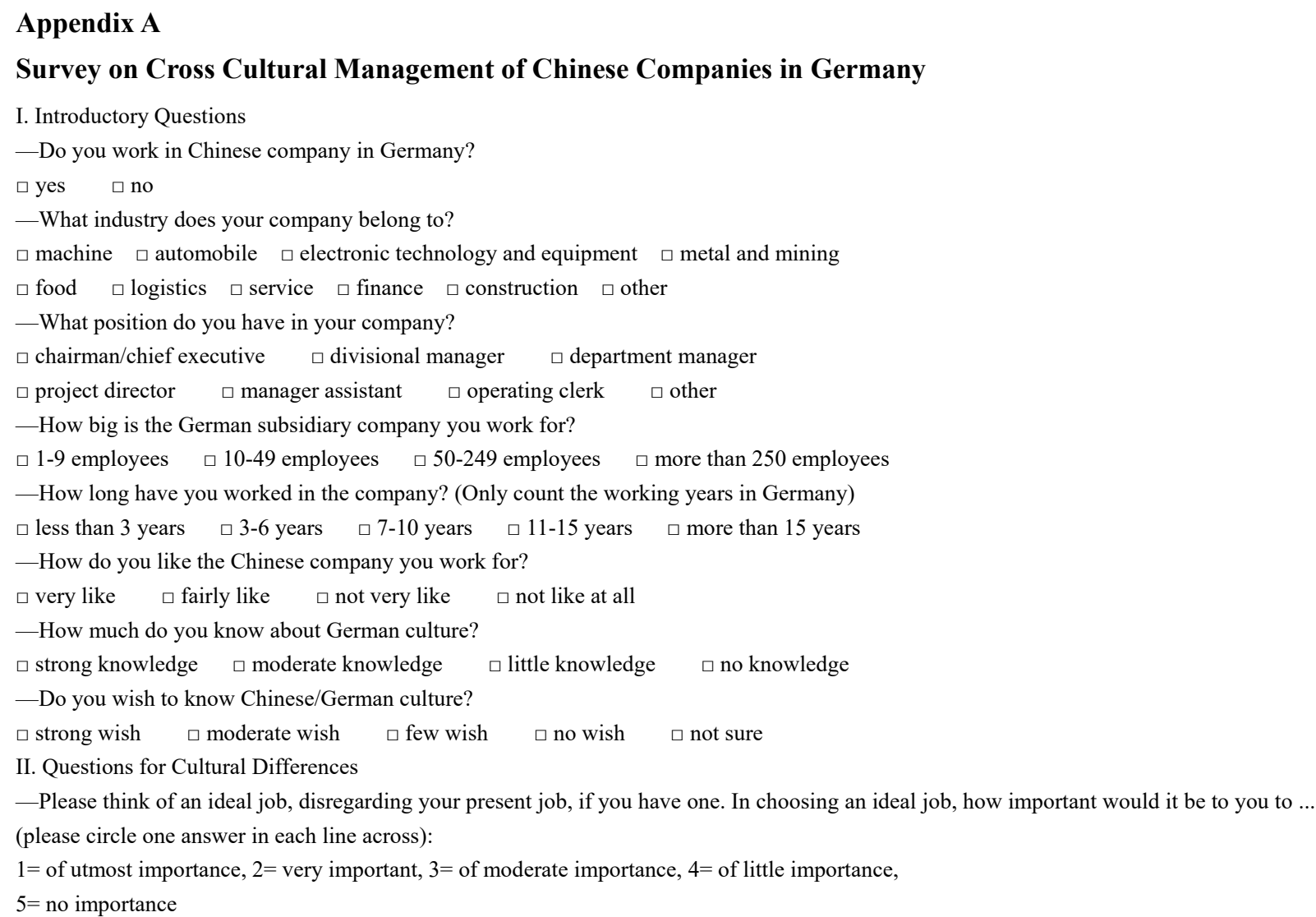




\begin{tabular}{l|lllcc}
\hline 01.have sufficient time for your personal or home life & $\square 1$ & $\square 2$ & $\square 3$ & $\square 4$ & $\square 5$ \\
02.have a direct superior you can respect & $\square 1$ & $\square 2$ & $\square 3$ & $\square 4$ & $\square 5$ \\
\hline 03.get recognition for good performance & $\square 1$ & $\square 2$ & $\square 3$ & $\square 4$ & $\square 5$ \\
\hline 04.have security of employment & $\square 1$ & $\square 2$ & $\square 3$ & $\square 4$ & $\square 5$ \\
05.have pleasant people to work with & $\square 1$ & $\square 2$ & $\square 3$ & $\square 4$ & $\square 5$ \\
\hline 06.do work that is interesting & $\square 1$ & $\square 2$ & $\square 3$ & $\square 4$ & $\square 5$ \\
07.be consulted by your boss in decisions involving your work & $\square 1$ & $\square 2$ & $\square 3$ & $\square 4$ & $\square 5$ \\
08.live in a desirable area & $\square 1$ & $\square 2$ & $\square 3$ & $\square 4$ & $\square 5$ \\
09.have a job respected by your family and friends & $\square 1$ & $\square 2$ & $\square 3$ & $\square 4$ & $\square 5$ \\
\hline 10.have chances for promotion & $\square 1$ & $\square 2$ & $\square 3$ & $\square 4$ & $\square 5$ \\
\hline
\end{tabular}

-In your private life, how important is each of the following to you (please circle one answer in each line across):

$1=$ of utmost importance, $2=$ very important, $3=$ of moderate importance, $4=$ of little importance,

$5=$ no importance

\begin{tabular}{|c|c|c|c|c|c|c|}
\hline \multicolumn{3}{|c|}{ 11.keeping time free for fun } & $\square 2$ & $\square 3$ & $\square 4$ & $\square 5$ \\
\hline \multicolumn{3}{|c|}{ 12.moderation: having few desires } & $\square 2$ & $\square 3$ & $\square 4$ & $\square 5$ \\
\hline \multicolumn{3}{|c|}{ 13.doing a service to a friend } & $\square 2$ & $\square 3$ & $\square 4$ & $\square 5$ \\
\hline \multicolumn{3}{|c|}{ 14.thrift (not spending more than needed) } & $\square 2$ & $\square 3$ & $\square 4$ & $\square 5$ \\
\hline \multicolumn{3}{|c|}{$\square 1=$ always $\square 2=$ usually $\square 3=$ sometimes $\square 4=$ seldom $\square 5=$ never } & & & & \\
\hline \multicolumn{6}{|c|}{ 16.Are you a happy person? } & $\square 1=$ always $\square 2=$ usually $\square 3=$ sometimes $\quad \square 4=$ seldom $\quad \square 5=$ never \\
\hline \multicolumn{7}{|c|}{$\begin{array}{l}\text { 17. Do other people or circumstances ever prevent you from doing what you really want to? } \\
\square 1=\text { yes, always } \square 2=\text { yes, usually } \square 3=\text { sometimes } \square 4=\text { no, seldom } \quad \square 5=\text { no, never }\end{array}$} \\
\hline \multicolumn{6}{|c|}{ 18.All in all, how would you describe your state of health these days? } & $\square 1=$ very good $\square 2=$ good $\square 3=$ fair $\square 4=$ poor $\square 5=$ very poor \\
\hline \multicolumn{7}{|c|}{ 19.How proud are you to be a citizen of your country? } \\
\hline \multicolumn{5}{|c|}{ 20.How often, in your experience, are your subordinates afraid to contradict you? } & & \\
\hline
\end{tabular}

-To what extent do you agree or disagree with each of the following statements? (please circle one answer in each line across):

$1=$ strongly agree, $2=$ agree, $3=$ undecided, $4=$ disagree, $5=$ strongly disagree

21.One can be a good manager without having a precise answer to every question that a subordinate may raise about his or her work

22.Persistent efforts are the surest way to results

23.An organization structure in which certain subordinates have two bosses should be avoided at all cost

24.A company's or organization's rules should not be broken - not even when the employee thinks breaking the rule would be in the organization's best interest

\begin{tabular}{|c|c|c|c|c|}
\hline$\square 1$ & $\square 2$ & $\square 3$ & $\square 4$ & $\square 5$ \\
\hline$\square 1$ & $\square 2$ & $\square 3$ & $\square 4$ & $\square 5$ \\
\hline$\square 1$ & $\square 2$ & $\square 3$ & $\square 4$ & $\square 5$ \\
\hline$\square 1$ & $\square 2$ & $\square 3$ & $\square 4$ & $\square 5$ \\
\hline
\end{tabular}


III. Questions for Organizational Conflict-A

-Please check the appropriate box after each statement, to indicate how you handle your disagreement or conflict with your subordinates. Try to recall as many recent conflict situations as possible in ranking these statements. (please circle one answer in each line across)

$1=$ strongly disagree, $2=$ disagree, $3=$ not sure, $4=$ agree, $5=$ strongly agree

\begin{tabular}{|c|c|c|c|c|c|}
\hline 01.I try to investigate an issue with my subordinates to find a solution acceptable to us & $\square 1$ & $\square 2$ & $\square 3$ & $\square 4$ & $\square 5$ \\
\hline 02.I generally try to satisfy the needs of my subordinates & $\square 1$ & $\square 2$ & $\square 3$ & $\square 4$ & $\square 5$ \\
\hline $\begin{array}{l}\text { 03.I attempt to avoid being "put on the spot" and try to keep my conflict with my subordinates to } \\
\text { myself }\end{array}$ & $\square 1$ & $\square 2$ & $\square 3$ & $\square 4$ & $\square 5$ \\
\hline 04.I try to integrate my ideas with those of my subordinates to come up with a decision jointly & $\square 1$ & $\square 2$ & $\square 3$ & $\square 4$ & $\square 5$ \\
\hline 05.I try to work with my subordinates to find solutions to a problem which satisfy our expectations & $\square 1$ & $\square 2$ & $\square 3$ & $\square 4$ & $\square 5$ \\
\hline 06.I usually avoid open discussion of my differences with my subordinates & $\square 1$ & $\square 2$ & $\square 3$ & $\square 4$ & $\square 5$ \\
\hline 07.I try to find a middle course to resolve an impasse & $\square 1$ & $\square 2$ & $\square 3$ & $\square 4$ & $\square 5$ \\
\hline 08.I use my influence to get my ideas accepted & $\square 1$ & $\square 2$ & $\square 3$ & $\square 4$ & $\square 5$ \\
\hline 09.I use my authority to make a decision in my favor & $\square 1$ & $\square 2$ & $\square 3$ & $\square 4$ & $\square 5$ \\
\hline 10.I usually accommodate the wishes of my subordinates & $\square 1$ & $\square 2$ & $\square 3$ & $\square 4$ & $\square 5$ \\
\hline 11.I give in to the wishes of my subordinates & $\square 1$ & $\square 2$ & $\square 3$ & $\square 4$ & $\square 5$ \\
\hline 12.I exchange accurate information with my subordinates to solve a problem together & $\square 1$ & $\square 2$ & $\square 3$ & $\square 4$ & $\square 5$ \\
\hline 13.I usually allow concessions to my subordinates & $\square 1$ & $\square 2$ & $\square 3$ & $\square 4$ & $\square 5$ \\
\hline 14.I usually propose a middle ground for breaking deadlocks & $\square 1$ & $\square 2$ & $\square 3$ & $\square 4$ & $\square 5$ \\
\hline 15.I negotiate with my subordinates so that a compromise can be reached & $\square 1$ & $\square 2$ & $\square 3$ & $\square 4$ & $\square 5$ \\
\hline 16.I try to stay away from disagreement with my subordinates & $\square 1$ & $\square 2$ & $\square 3$ & $\square 4$ & $\square 5$ \\
\hline 17.I avoid an encounter with my subordinates & $\square 1$ & $\square 2$ & $\square 3$ & $\square 4$ & $\square 5$ \\
\hline 18.I use my expertise to make a decision in my favor & $\square 1$ & $\square 2$ & $\square 3$ & $\square 4$ & $\square 5$ \\
\hline 19.I often go along with the suggestions of my subordinates & $\square 1$ & $\square 2$ & $\square 3$ & $\square 4$ & $\square 5$ \\
\hline 20.I use "give and take" so that a compromise can be made & $\square 1$ & $\square 2$ & $\square 3$ & $\square 4$ & $\square 5$ \\
\hline 21.I am generally firm in pursuing my side of the issue & $\square 1$ & $\square 2$ & $\square 3$ & $\square 4$ & $\square 5$ \\
\hline $\begin{array}{l}\text { 22.I try to bring all our concerns out in the open so that the issues can be resolved in the best } \\
\text { possible way }\end{array}$ & $\square 1$ & $\square 2$ & $\square 3$ & $\square 4$ & $\square 5$ \\
\hline 23.I collaborate with my subordinates to come up with decisions acceptable to us & $\square 1$ & $\square 2$ & $\square 3$ & $\square 4$ & $\square 5$ \\
\hline 24.I try to satisfy the expectations of my subordinates & $\square 1$ & $\square 2$ & $\square 3$ & $\square 4$ & $\square 5$ \\
\hline 25.I sometimes use my power to win a competitive situation & $\square 1$ & $\square 2$ & $\square 3$ & $\square 4$ & $\square 5$ \\
\hline 26.I try to keep my disagreement with my subordinates to myself in order to avoid hard feelings & $\square 1$ & $\square 2$ & $\square 3$ & $\square 4$ & $\square 5$ \\
\hline 27.I try to avoid unpleasant exchanges with my subordinates & $\square 1$ & $\square 2$ & $\square 3$ & $\square 4$ & $\square 5$ \\
\hline 28.I try to work with my subordinates for a proper understanding of a problem & $\square 1$ & $\square 2$ & $\square 3$ & $\square 4$ & $\square 5$ \\
\hline
\end{tabular}

IV. Demographic Questions

-What is your nationality?

$\square$ German $\square$ Chinese $\square$ other

-What is your gender?

$\square$ male $\square$ female

- How old are you?

$\square$ younger than $20 \quad \square 20-29 \quad \square 30-39 \quad \square 40-49 \quad \square 50-59 \quad \square$ older than 60

-What is your last university or college degree?

$\square$ bachelor $\square$ master $\square$ doctorate $\square$ other

If you are interested in my research and want to receive the results, I would like to send the results to you after completing the study of my dissertation.

(It is optional. If you want it, please leave your Email)

Email Address

After this survey, I will invite some respondents to make an interview.

(It is optional. If you would like to do this, please fill out the following blanks for our contact)

Name Email Address

Telephone

Name of the Company You Work for

Address of the Company

Other Contact Ways or Some Requirements about Interview 


\section{Appendix B}

\section{Interview Guideline}

Interviewee's experience

- have you worked in local companies of Germany previously? compared with the current company where you work, describe some possible differences on methods or attitudes of treating conflict.

- could you please give me an example of a typical conflict case?

- does difference exist in handling conflict with Chinese and with German subordinates? If yes, describe a case to demonstrate the difference.

- how often do conflicts take place between you and your subordinates?

- facing with various conflicts every day, how you handle them in limited time?

Interviewee's reactions to relevant experience

- how do you think of the role of working relationship in handling conflict?

- if managers place much attention to personal authority or leadership in workplace, what consequences will take place?

- while handling a conflict between you and your subordinate, what do you think of the priority of the involving parties' interests or needs?

- what do you think of the role of regulations in conflict management?

- what element is the key to manage a conflict in workplace?

- what do you think of giving up personal immediate gratifications for conflict management?

Interviewee's thinking on relationship between culture and conflict management

- what do you think of the role of national culture in business management, especially its role in management of Chinese companies in Germany?

- under the influence of localization, many companies argue that there exists no problem concerning intercultural communication and management in companies. What do you think of it?

- what do you think of the role of conflict in business management and development of companies?

- apart from the influence of organizational culture, how do your national cultural traits influence the way of handling conflict?

- what cultural trait is typical element of influencing conflict?

\section{Copyrights}

Copyright for this article is retained by the author(s), with first publication rights granted to the journal.

This is an open-access article distributed under the terms and conditions of the Creative Commons Attribution license (http://creativecommons.org/licenses/by/4.0/). 